\title{
Antioxidant, Anti-tyrosinase, Anti- $\alpha$-amylase, and Cytotoxic Potentials of the Invasive Weed Andropogon virginicus
}

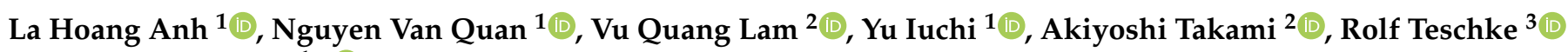 \\ and Tran Dang Xuan $1, *$ (D)
}

1 Transdisciplinary Science and Engineering Program, Graduate School of Advanced Science and Engineering, Hiroshima University, Hiroshima 739-8529, Japan; hoanganh6920@gmail.com (L.H.A.); nvquan@hiroshima-u.ac.jp (N.V.Q.); iuchiyu0311@gmail.com (Y.I.)

2 Division of Hematology, Department of Internal Medicine, Aichi Medical University School of Medicine, Nagakute 480-1195, Japan; quanglamvu1991@gmail.com (V.Q.L.); takami.akiyoshi.490@mail.aichi-med-u.ac.jp (A.T.)

3 Department of Internal Medicine II, Division of Gastroenterology and Hepatology, Klinikum Hanau, Teaching Hospital of the Medical Faculty, Goethe University Frankfurt/Main, 63450 Hanau, Germany; rolf.teschke@gmx.de

* Correspondence: tdxuan@hiroshima-u.ac.jp; Tel./Fax: +81-82-424-6927

Citation: Anh, L.H.; Quan, N.V.; Lam, V.Q.; Iuchi, Y.; Takami, A.; Teschke, R.; Xuan, T.D. Antioxidant, Antityrosinase, Anti- $\alpha$-amylase, and Cytotoxic Potentials of the Invasive Weed Andropogon virginicus. Plants 2021, 10, 69. https://doi.org/ 10.3390/plants10010069

Received: 7 December 2020 Accepted: 25 December 2020 Published: 31 December 2020

Publisher's Note: MDPI stays neutral with regard to jurisdictional clai$\mathrm{ms}$ in published maps and institutional affiliations.

Copyright: (C) 2020 by the authors. Licensee MDPI, Basel, Switzerland. This article is an open access article distributed under the terms and conditions of the Creative Commons Attribution (CC BY) license (https:// creativecommons.org/licenses/by/ $4.0 /)$.

\begin{abstract}
Andropogon virginicus is an invasive weed that seriously threatens agricultural production and economics worldwide. In this research, dried aerial parts of $A$. virginicus were extracted, applying Soxhlet and liquid-liquid phase methods to acquire the total crude (T-Anvi), hexane (H-Anvi), ethyl acetate (E-Anvi), butanol (B-Anvi), and water (W-Anvi) extracts, respectively. In which, T-Anvi contains the highest total phenolic and flavonoid contents $(24.80 \mathrm{mg}$ gallic acid and $37.40 \mathrm{mg}$ rutin equivalents per g dry weight, respectively). Via anti-radical (ABTS and DPPH), and reducing power assays, E-Anvi exhibits the most potent activities $\left(\mathrm{IC}_{50}=13.96,43.59\right.$ and $124.11 \mu \mathrm{g} / \mathrm{mL}$, respectively), stronger than butylated hydroxytoluene (BHT), a standard antioxidant, while the lipid peroxidation inhibitory effect of E-Anvi (LPI $=90.85 \%$ at the concentration of $500 \mu \mathrm{g} / \mathrm{mL}$ ) is close to BHT. E-Anvi shows the most substantial inhibition $\left(\mathrm{IC}_{50}=2.58 \mathrm{mg} / \mathrm{mL}\right)$ on tyrosinase. Notably, $\alpha$-amylase is significantly suppressed by $\mathrm{H}$-Anvi $\left(\mathrm{IC}_{50}=0.72 \mathrm{mg} / \mathrm{mL}\right)$, over twice stronger than the positive control, palmitic acid. In the cytotoxic assay, E-Anvi is the strongest extract inhibiting $\mathrm{K} 562$ cells $\left(\mathrm{IC}_{50}=112.01 \mu \mathrm{g} / \mathrm{mL}\right)$. Meanwhile, T-Anvi shows the highest prevention on Meg-01 expansion $\left(\mathrm{IC}_{50}=91.40 \mu \mathrm{g} / \mathrm{mL}\right.$ ). Dominant compounds detected in E-Anvi by highperformance liquid chromatography-electrospray ionization-tandem mass spectrometry (HPLCESI-MS/MS) are identified as flavonoids. However, among four major compounds identified in $\mathrm{H}$-Anvi by gas chromatography-mass spectrometry (GC-MS), palmitic acid and phytol are the most abundant compounds with peak areas of $27.97 \%$ and $16.42 \%$, respectively. In essence, this is the first report describing that $A$. virginicus is a potential natural source of antioxidants, tyrosinase and $\alpha$-amylase inhibitors, and anti-chronic myeloid leukemia (CML) agents which may be useful in future therapeutics as promising alternative medicines.
\end{abstract}

Keywords: Andropogon virginicus; antioxidants; $\alpha$-amylase inhibitor; tyrosinase inhibitor; antichronic myeloid leukemia; anti-diabetes; anti-skin aging; high-performance liquid chromatographyelectrospray ionization-tandem mass spectrometry; gas chromatography-mass spectrometry

\section{Introduction}

Andropogon virginicus is an invasive weed that is widely distributed in the world. The weed is described as an herbaceous, perennial, C4 plant. A. virginicus grows densely and up to $210 \mathrm{~cm}$ high [1]. Though this species has been sold in some regions such as Europe, it has been generally considered as not having economic value [2]. Moreover, the strong invasiveness of $A$. virginicus is threatening biodiversity [3,4]. In particular, this 
weed is problematically competing with endangered plant species like Tetramolopium remyi, Santalum freycinetianum var. lanaiense, and Schiedea nuttallii [2,5]. Due its dense and robust growth, $A$. virginicus has also a negative impact on horticultural systems. For instance, it degrades the farmlands of Charmhaven apple in Australia [6]. In addition, A. virginicus is dealing a blow economically to the forage and timber production in the southeastern USA because of high competition [2]. In soil, the weed also affects the cycle of nitrogen and water content leading to a decrease in the abundance of native species [7]. Considering that A. virginicus is hardly to be controlled and causes numerous serious problems, this invasive weed has received little attention from scientists. Hitherto, no effective strategy has been proposed to control the invasiveness or obtain the benefits of $A$. virginicus for human purposes. Therefore, an effective management of this natural resource is urgently needed, considering the potential of many other plants for therapeutic use, an attractive field of current research. Numerous plant species with antioxidant, anti-inflammatory, antibacterial, antiviral, anti-skin aging, and anticancer properties have been globally known [8]. However, the biological activities related to antioxidant, anti-tyrosinase, anti- $\alpha$-amylase, and cytotoxic properties of the invasive weed $A$. virginicus have not been studied in detail.

In humans, oxidative stress is tightly linked to inflammation, claimed as a central physiological process in the pathogenesis of numerous chronic diseases including diabetes, aging, and cancer [9]. Concretely, the inflammatory process can exacerbate oxidative stress and vice versa [9-15]. In fact, many experimental data have indicated the existence and contribution of oxidative stress in several chronic diseases [13-22]. Therefore, the screening of sample's antioxidant property is an integral part of our study. Of the serious chronic diseases, diabetes is a complicated disorder with different types requiring varied treatment methods. The most common diabetes is type 2, which causes the elevation of bloodstream sugar level. A potential approach to mitigate type 2 diabetes' effects can be mentioned to inhibit important enzymes involving in glucose formation, in which $\alpha$-amylase is a crucial enzyme acting on starch [23]. Additionally, a strong correlation between diabetes and skin manifestations was reported via clinical tests and practical trials [24,25]. Among skin problems, hyperpigmentation resulting in freckles is attributed to the over-formation of melanin through an abnormal tyrosinase activity at both normal melanocytes and malignant melanoma cells [25]. For that reason, the simultaneous inhibition on $\alpha$-amylase and tyrosinase can be an effective solution to avoid the symptom of type 2 diabetes and skin hyperpigmentation. In cancer cases, chronic myeloid leukemia (CML) is a severe disorder, caused by the unregular proliferation of myeloid cells in the bone marrow. K562 is a typical CML cell line relating to an extraordinary increase in the production of white blood cells [26-28]. Meg-01 cell line is also considered to be derived from the myeloid origin, which involve in proliferating nonfunctional immature cells, another type of CML $[27,29,30]$. Therefore, simultaneous inhibition on both K562 and Meg-01 can be a potential solution in preventing the development of CML. Furthermore, the synergic suppression against oxidative stress, tyrosinase and $\alpha$-amylase enzymes, and K562 and Meg-01 cell lines could be a prospective approach for developing natural products, which can prevent multiple human health problems.

This research was conducted to look for potential phytochemicals and pharmaceutical properties of the invasive weed $A$. virginicus with focus on antioxidant, anti-skin aging, anti-diabetes, and anticancer properties. Relevant phytochemicals from this invasive species were identified using high-performance liquid chromatography-electrospray ionization-tandem mass spectrometry (HPLC-ESI-MS/MS) and gas chromatography-mass spectrometry (GC-MS).

\section{Results}

2.1. Yield and Total Phenolic (TPC) and Flavonoid (TFC) Contents of Extracts from A. virginicus

From $10 \mathrm{~g}$ of $A$. virginicus dried samples, five extracts were obtained including total (T-Anvi), hexane (H-Anvi), ethyl acetate (E-Anvi), butanol (B-Anvi), and water (W-Anvi) 
extracts. The yield of T-Anvi is $0.98 \mathrm{~g}(9.8 \%)$, followed by E-Anvi $(0.32 \mathrm{~g}, 3.2 \%)$, H-Anvi (0.16 g, 1.6\%), B-Anvi (0.12 g, 1.2\%), and W-Anvi (0.11 g, 1.1\%) (Table 1).

Table 1. Extraction yield and total phenolic (TPC) and flavonoid (TFC) contents.

\begin{tabular}{ccccc}
\hline Samples & Code & Extraction Yield (\%) & $\begin{array}{c}\text { TPC } \\
\text { (mg GAE/g DW) }\end{array}$ & $\begin{array}{c}\text { TFC } \\
\text { (mg RE/g DW) }\end{array}$ \\
\hline Total crude extract & T-Anvi & 9.8 & $24.80 \pm 0.51^{\mathrm{a}}$ & $37.40 \pm 0.74^{\mathrm{a}}$ \\
Hexane extract & H-Anvi & 1.6 & $1.26 \pm 0.03^{\mathrm{c}}$ & $6.30 \pm 0.13^{\mathrm{c}}$ \\
Ethyl acetate extract & E-Anvi & 3.2 & $25.34 \pm 0.47^{\mathrm{a}}$ & $25.44 \pm 0.45^{\mathrm{b}}$ \\
Butanol extract & B-Anvi & 1.2 & $3.26 \pm 0.06^{\mathrm{b}}$ & $4.91 \pm 0.08^{\mathrm{d}}$ \\
Water extract & W-Anvi & 1.1 & $0.49 \pm 0.01^{\mathrm{c}}$ & $0.25 \pm 0.01^{\mathrm{e}}$ \\
\hline
\end{tabular}

Data express means \pm standard deviation (SD). Different superscript letters in a column indicate significant differences at $p<0.05$. TPC, total phenolic content; TFC, total flavonoid content; GAE, gallic acid equivalent; RE, rutin equivalent; DW, dry weight.

The TPC results of extracts from A. virginicus range from 0.49 to $25.34 \mathrm{mg}$ GAE/g DW. In which, E-Anvi and T-Anvi show the highest TPC of 25.34 and $24.80 \mathrm{mg}$ GAE/g DW, respectively, which are significantly higher than B-Anvi, H-Anvi, and W-Anvi with TPC of 3.26, 1.26, and $0.49 \mathrm{mg} \mathrm{GAE/g} \mathrm{DW,} \mathrm{respectively.} \mathrm{Similarly,} \mathrm{the} \mathrm{highest} \mathrm{TFC} \mathrm{is} \mathrm{found} \mathrm{in}$ T-Anvi (37.40 mg RE/g DW). The following fractional extracts including E-Anvi, H-Anvi, B-Anvi, and W-Anvi account for $68.0 \%, 16.8 \%, 13.1 \%$, and $0.8 \%$, respectively, in comparison with TFC of T-Anvi (Table 1).

\subsection{Antioxidant Activity of Extracts from A. virginicus}

The antioxidant activity of extracts from $A$. virginicus is determined via ABTS, DPPH, $\beta$-carotene bleaching, and reducing power assays (Table 2).

Table 2. Anti-radical activities of $A$. virginicus extracts.

\begin{tabular}{ccc}
\hline Samples & $\begin{array}{c}\text { ABTS Assay } \\
\text { IC }_{50}(\mu \mathrm{g} / \mathrm{mL})\end{array}$ & $\begin{array}{c}\text { DPPH Assay } \\
\text { IC }_{50}(\boldsymbol{\mu g} / \mathbf{m L})\end{array}$ \\
\hline T-Anvi & $77.71 \pm 1.85^{\mathrm{d}}$ & $30.54 \pm 0.40^{\mathrm{cd}}$ \\
H-Anvi & $323.88 \pm 1.22^{\mathrm{b}}$ & $126.27 \pm 4.92^{\mathrm{b}}$ \\
E-Anvi & $43.59 \pm 1.25^{\mathrm{f}}$ & $13.96 \pm 0.39^{\mathrm{e}}$ \\
B-Anvi & $86.73 \pm 2.30^{\mathrm{c}}$ & $33.79 \pm 0.24^{\mathrm{c}}$ \\
W-Anvi & $586.31 \pm 6.11^{\mathrm{a}}$ & $386.91 \pm 8.24^{\mathrm{a}}$ \\
BHT & $63.51 \pm 0.43^{\mathrm{e}}$ & $20.81 \pm 0.67^{\mathrm{de}}$ \\
\hline
\end{tabular}

Data express means \pm standard deviation (SD). Different superscript letters in a column indicate significant differences at $p<0.05$. DPPH, 2,2-diphenyl-1-picrylhydrazyl; ABTS, 2,2'-azinobis-(3-ethylbenzothiazoline-6sulfonic acid); T-Anvi, total crude extract; $\mathrm{H}$-Anvi, hexane extract; E-Anvi, ethyl acetate extract; B-Anvi, butanol extract; W-Anvi, water extract; BHT, butylated hydroxytoluene.

In the ABTS assay, the results in Table 2 show that almost samples reveal strong inhibition on ABTS cations, except for H-Anvi and W-Anvi with $\mathrm{IC}_{50}$ values of 323.88 and $586.31 \mu \mathrm{g} / \mathrm{mL}$, respectively. The samples including T-Anvi and B-Anvi show $\mathrm{IC}_{50}$ values of 77.71 and $86.73 \mu \mathrm{g} / \mathrm{mL}$, respectively, which are close to the positive control, BHT, a well-known antioxidant agent. Remarkably, E-Anvi $\left(\mathrm{IC}_{50}=43.59 \mu \mathrm{g} / \mathrm{mL}\right)$ shows stronger scavenging ability against ABTS cations than BHT.

In the DPPH assay, all samples have scavenging effects on DPPH. In which, $\mathrm{IC}_{50}$ values are ranged from 13.96 to $386.91 \mu \mathrm{g} / \mathrm{mL}$. H-Anvi and W-Anvi repeat the weakest activity with $\mathrm{IC}_{50}$ values of 126.27 and $386.91 \mu \mathrm{g} / \mathrm{mL}$, respectively. While T-Anvi and B-Anvi display similar activity with $\mathrm{IC}_{50}$ values of more than $30.00 \mu \mathrm{g} / \mathrm{mL}$. Significantly, E-Anvi exhibits the highest scavenging capacity against $\mathrm{DPPH}$ with $\mathrm{IC}_{50}$ value of $13.96 \mu \mathrm{g} / \mathrm{mL}$, which is approximately twice stronger than BHT (Table 2).

In the case of $\beta$-carotene bleaching model, all samples display strong inhibition on lipid peroxidation, which is close to the standard, BHT (LPI $=94.22 \%)$, except for W-Anvi 
$(\mathrm{LPI}=81.65 \%)$. The strongest sample is B-Anvi $(\mathrm{LPI}=92.05 \%)$, followed by E-Anvi (LPI = 90.85\%), T-Anvi (LPI = 90.81\%), and H-Anvi (LPI = 90.17\%) (Figure 1).

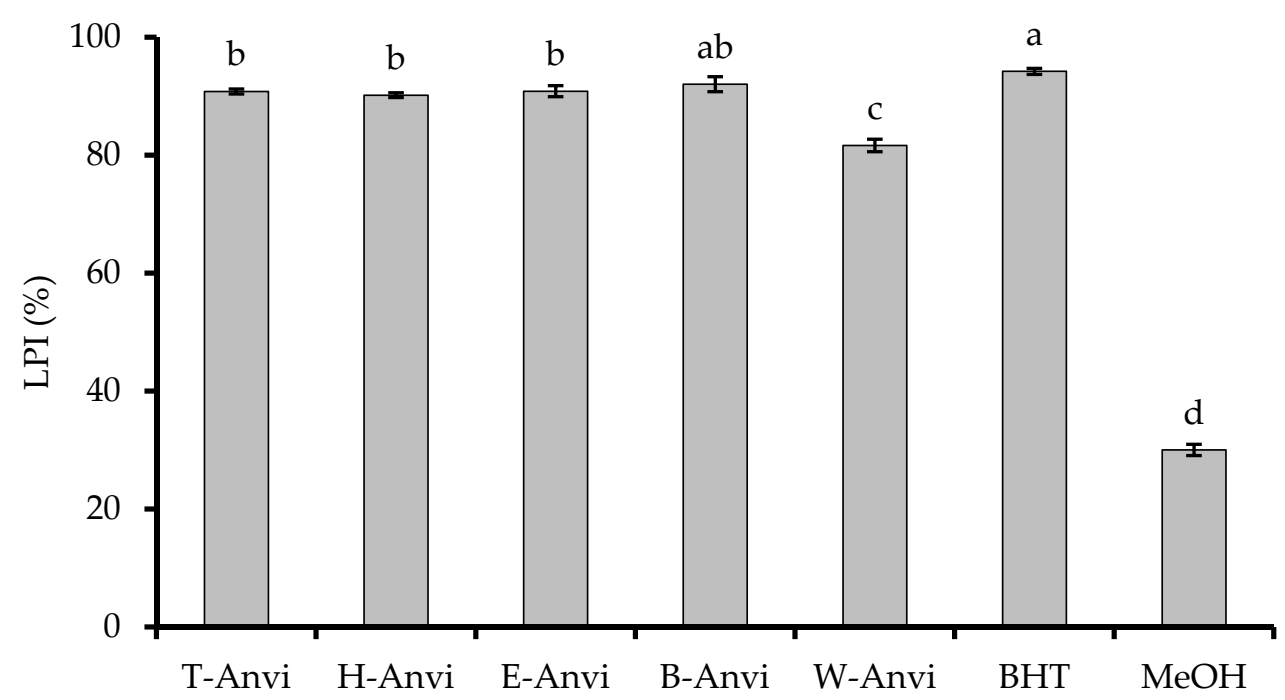

Figure 1. Inhibition on lipid peroxidation of A. virginicus extracts. Different letters indicate significant differences at $p<0.05$. LPI, lipid peroxidation inhibition; T-Anvi, total crude extract; H-Anvi, hexane extract; E-Anvi, ethyl acetate extract; B-Anvi, butanol extract; W-Anvi, water extract; BHT, butylated hydroxytoluene.

In the reducing power assay, by comparing $\mathrm{IC}_{50}$ values between samples and controls, we obtain that E-Anvi shows the most substantial power $\left(\mathrm{IC}_{50}=124.11 \mu \mathrm{g} / \mathrm{mL}\right), 1.4$-fold stronger than the positive standard, $\mathrm{BHT}\left(\mathrm{IC}_{50}=175.52 \mu \mathrm{g} / \mathrm{mL}\right)$. The following extracts are T-Anvi $\left(\mathrm{IC}_{50}=257.35 \mu \mathrm{g} / \mathrm{mL}\right)$ and B-Anvi $\left(\mathrm{IC}_{50}=340.62 \mu \mathrm{g} / \mathrm{mL}\right)$. The weakest samples including $\mathrm{H}-\mathrm{Anvi}$ and $\mathrm{W}-\mathrm{Anvi}$ reveal trivial reducing power (Figure 2).

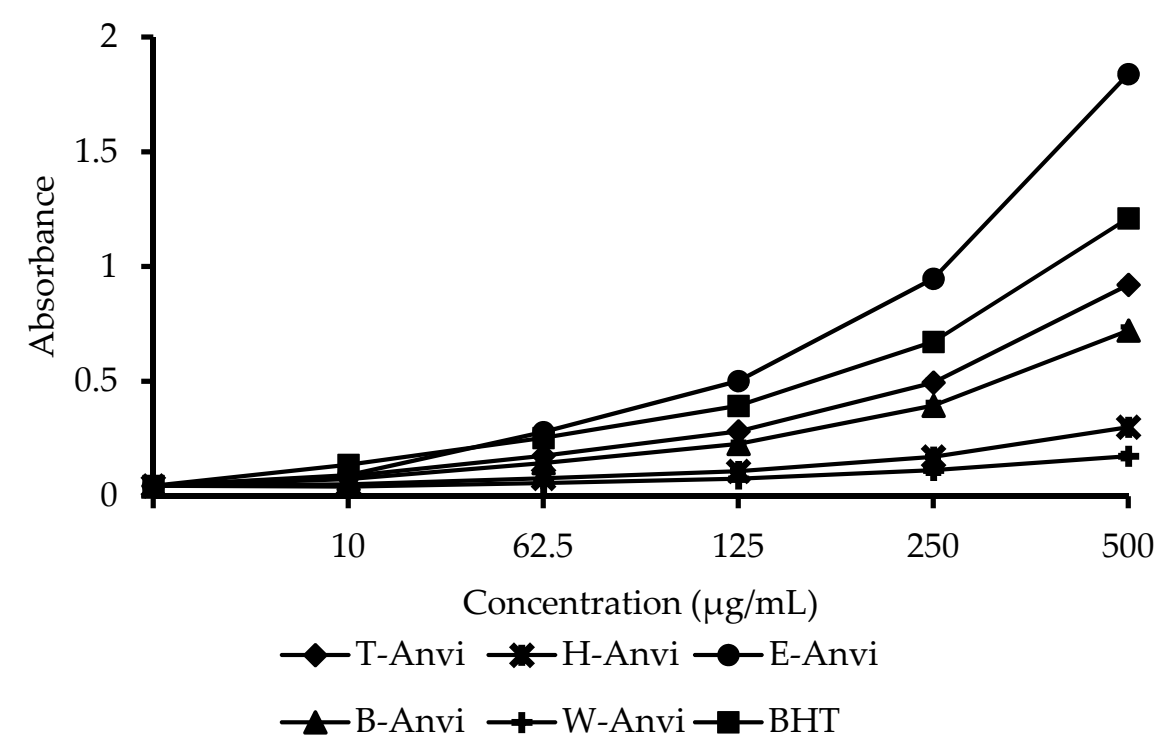

Figure 2. Potassium ferricyanide reducing power of A. virginicus extracts. T-Anvi, total crude extract; $\mathrm{H}$-Anvi, hexane extract; E-Anvi, ethyl acetate extract; B-Anvi, butanol extract; W-Anvi, water extract; BHT, butylated hydroxytoluene.

\subsection{Tyrosinase and $\alpha$-Amylase Inhibitory Activities of A. virginicus Extracts}

In the tyrosinase enzymatic assay, the results show that almost samples have inhibitory effects. Among them, the strongest sample is E-Anvi with $\mathrm{IC}_{50}$ value of $2.58 \mathrm{mg} / \mathrm{mL}$. The 
following samples including T-Anvi, H-Anvi, and B-Anvi have $\mathrm{IC}_{50}$ values of 4.57, 6.22, and $9.40 \mathrm{mg} / \mathrm{mL}$, respectively. W-Anvi has no effect on the enzyme (Table 3).

Table 3. Tyrosinase and $\alpha$-amylase inhibitory activities of $A$. virginicus extracts.

\begin{tabular}{ccc}
\hline Samples & $\begin{array}{c}\text { Tyrosinase Inhibition } \\
\mathbf{I C}_{\mathbf{5 0}}(\mathbf{m g} / \mathbf{m L})\end{array}$ & $\begin{array}{c}\alpha \text {-Amylase Inhibition } \\
\text { IC }_{\mathbf{5 0}}(\mathbf{m g} / \mathbf{m L})\end{array}$ \\
\hline T-Anvi & $4.57 \pm 0.05^{\mathrm{c}}$ & $3.48 \pm 0.07^{\mathrm{a}}$ \\
H-Anvi & $6.22 \pm 0.08^{\mathrm{b}}$ & $0.72 \pm 0.01^{\mathrm{c}}$ \\
E-Anvi & $2.58 \pm 0.13^{\mathrm{d}}$ & ne \\
B-Anvi & $9.40 \pm 0.02^{\mathrm{a}}$ & ne \\
W-Anvi & na & na \\
Kojic acid & $0.02 \pm 0.00^{\mathrm{e}}$ & - \\
Palmitic acid & - & $1.57 \pm 0.04^{\mathrm{b}}$ \\
\hline
\end{tabular}

Data express means \pm standard deviation (SD). Different superscript letters in a column indicate significant differences at $p<0.05$. T-Anvi, total crude extract; H-Anvi, hexane extract; E-Anvi, ethyl acetate extract; B-Anvi, butanol extract; W-Anvi, water extract; na, no activity; ne, negligible effect; -, not determined.

While $\alpha$-amylase is strongly inhibited by the samples including H-Anvi and T-Anvi with $\mathrm{IC}_{50}$ values of 0.72 and $3.48 \mathrm{mg} / \mathrm{mL}$, respectively. Notably, H-Anvi is recorded as over twice stronger than palmitic acid, a well-known $\alpha$-amylase inhibitor. The extracts including E-Anvi and B-Anvi display insignificant suppression on $\alpha$-amylase. At the concentration of $10 \mathrm{mg} / \mathrm{mL}$, they exhibit the inhibition percentages of $31.93 \%$ and $17.52 \%$, respectively. $\mathrm{W}$-Anvi has no effect on $\alpha$-amylase (Table 3).

\subsection{Cytotoxic Activity of Extracts from A. virginicus against K562 and Meg-01 Cell Lines}

The dose-response curves of $A$. virginicus extracts for cytotoxic effects against K562 and Meg-01 cell lines are presented in Figure 3. Accordingly, A. virginicus extracts show inhibitory activity against cell expansion.

(a)

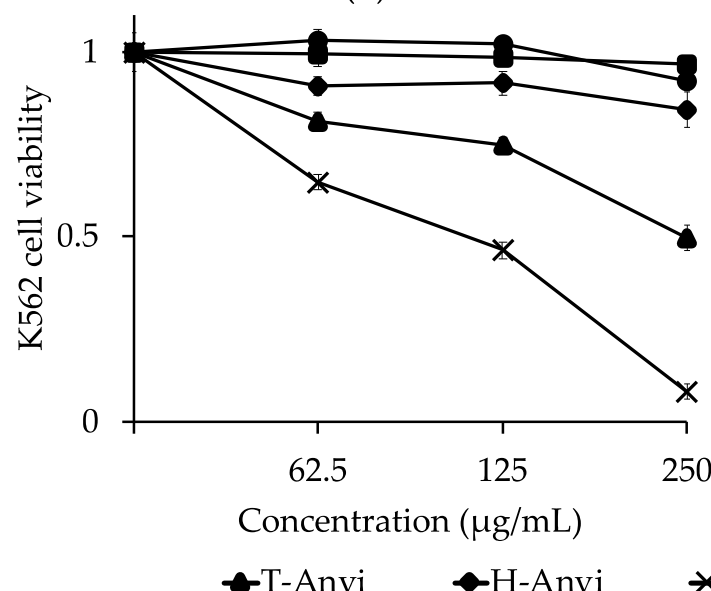

(b)

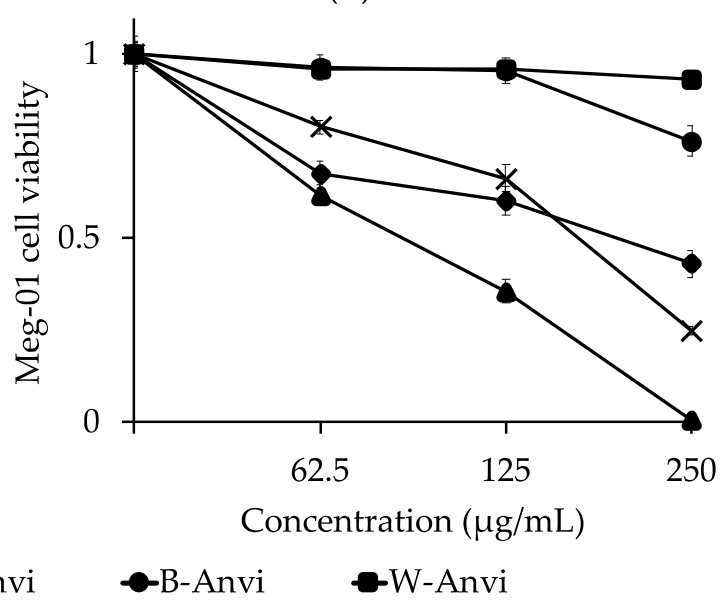

Figure 3. Dose-response curves of A. virginicus extracts for cytotoxicity against (a) K562 and (b) Meg-01 cell lines. T-Anvi, total crude extract; H-Anvi, hexane extract; E-Anvi, ethyl acetate extract; B-Anvi, butanol extract; W-Anvi, water extract.

For K562 cell line, E-Anvi exhibits the strongest inhibition with $\mathrm{IC}_{50}$ value of $112.01 \mu \mathrm{g} / \mathrm{mL}$. T-Anvi $\left(\mathrm{IC}_{50}=247.88 \mu \mathrm{g} / \mathrm{mL}\right)$ is twice weaker than E-Anvi. The remaining fractional extracts reveal insignificant suppression against K562 cell viability.

In the case of Meg-01 cell line, the extracts of T-Anvi, E-Anvi, and H-Anvi reveal substantial cytotoxicity with $\mathrm{IC}_{50}$ values of $91.40,168.94$, and $198.07 \mu \mathrm{g} / \mathrm{mL}$, respectively. While B-Anvi and W-Anvi have negligible prevention against Meg-01 cell viability (Figure 3). 


\subsection{Correlations between Total Phenolic (TPC) and Flavonoid (TFC) Contents and Biological Properties of A. virginicus Extracts}

The Pearson's correlation coefficients between TPC and TFC show that they have a strong association. Additionally, phenolics and flavonoids might be the main contributors to antioxidant activity via ABTS, DPPH, and reducing power assays. However, these compounds might not be involved in lipid peroxidation and $\alpha$-amylase inhibitory effects of $A$. virginnicus extracts. In contrast, flavonoids might be a vital factor determining the anti-tyrosinase ability. Significantly, the cytotoxicity on K562 and Meg-01 cell lines might be mainly based on the presence of phenolics, especially flavonoid compounds in extracts from A. virginicus. The results show that the extract inhibiting K562 cell viability can feasibly suppress Meg-01 as well. Moreover, via all tested assays, the synergic suppression of extracts from A. virginicus against various factors involving in human diseases is confirmed through the strong expressed correlation in value of antioxidant, anti-tyrosinase, and K562, Meg-01 cytotoxic activities. The detailed information is presented in Table 4.

Table 4. Pearson's correlation coefficients between total phenolic and flavonoid contents and biological activities of $A$. virginicus extracts.

\begin{tabular}{|c|c|c|c|c|c|c|c|c|c|}
\hline & TPC & TFC & ABTS & DPPH & $\beta-\mathrm{Ca}$ & $\mathbf{R P}$ & Tyro & $\alpha$-Amy & K562 \\
\hline TFC & $0.952 *$ & - & - & - & - & - & - & - & - \\
\hline ABTS & $0.833^{*}$ & $0.674 *$ & - & - & - & - & - & - & - \\
\hline DPPH & $0.813^{*}$ & 0.633 * & 0.993 * & - & - & - & - & - & - \\
\hline$\beta-\mathrm{Ca}$ & 0.423 & 0.466 & 0.589 * & 0.549 * & - & - & - & - & - \\
\hline $\mathbf{R P}$ & $0.843^{*}$ & $0.667^{*}$ & 0.987 * & 0.997 * & 0.523 * & - & - & - & - \\
\hline Tyro & 0.479 & $0.525 *$ & 0.601 * & 0.572 * & 0.970 * & $0.555^{*}$ & - & - & - \\
\hline$\alpha$-Amy & -0.236 & -0.043 & -0.439 & -0.416 & 0.217 & -0.391 & 0.302 & - & - \\
\hline K562 & $0.898 *$ & 0.736 * & 0.891 * & 0.914 * & 0.330 & $0.942 *$ & 0.393 & -0.307 & - \\
\hline Meg-01 & $0.787^{*}$ & $0.913 *$ & 0.404 & 0.378 & 0.435 & 0.424 & 0.526 * & 0.351 & 0.554 * \\
\hline
\end{tabular}

*, a significance at $p<0.05$; TPC, total phenolic content; TFC, total flavonoid content; ABTS, 2,2'-azinobis-(3-ethylbenzothiazoline-6-sulfonic acid) assay; DPPH, 2,2-diphenyl-1-picrylhydrazyl assay; $\beta$-Ca, $\beta$-carotene bleaching assay; RP, reducing power assay; Tyro, tyrosinase inhibitory assay; $\alpha$-Amy, $\alpha$-amylase inhibitory assay; K562, K562 cytotoxic assay; Meg-01, Meg-01 cytotoxic assay.

\subsection{GC-MS Results}

From the results of GC-MS chromatogram (Figure S1), there are four abundant compounds detected in H-Anvi, which are reported in Table 5. Among them, palmitic acid is the most abundant compound with a peak area of $27.97 \%$. Phytol is the second dominant compound with a peak area of $16.42 \%$. Other identified substances can be listed as 8 -methyl-1-undecene and $\gamma$-sitosterol with respective peak areas of $10.77 \%$ and $7.38 \%$. The linear retention index (LRI) and Kovats index (KI) were calculated and compared to the literature.

Table 5. Dominant phytochemicals in H-Anvi extract from A. vigirnicus identified by GC-MS.

\begin{tabular}{cccccccccc}
\hline No. & $\begin{array}{c}\text { Identified } \\
\text { Compound }\end{array}$ & $\begin{array}{c}\text { RT } \\
(\mathbf{m i n})\end{array}$ & MW & Formula & Classification & Peak Area (\%) & LRI & KI & $\begin{array}{c}\text { Content } \\
(\mathbf{m g} / \mathbf{g} \text { DW) }\end{array}$ \\
\hline 1 & Phytol & 15.80 & 296 & $\mathrm{C}_{20} \mathrm{H}_{40} \mathrm{O}$ & Diterpenoids & 16.42 & 1835 & 1835 \\
2 & 8-Methyl-1-undecene & 16.64 & 168 & $\mathrm{C}_{12} \mathrm{H}_{24}$ & Alkenes & 10.77 & 1916 & 1917 & - \\
3 & Palmitic acid & 17.02 & 256 & $\mathrm{C}_{16} \mathrm{H}_{32} \mathrm{O}_{2}$ & Fatty acids & 27.97 & 1955 & 1955 & 0.86 \\
4 & $\gamma$-Sitosterol & 28.34 & 414 & $\mathrm{C}_{29} \mathrm{H}_{50} \mathrm{O}$ & Steroids & 7.38 & - & - & - \\
\hline
\end{tabular}

RT, retention time; LRI, linear retention index; KI, Kovats index; DW, dry weight; -, not determined.

The quantification result shows that palmitic acid accounts for $0.86 \mathrm{mg}$ per $1 \mathrm{~g}$ of A. virginicus dry weight. While in $1 \mathrm{~g}$ of $\mathrm{H}$-Anvi dried extract, $0.05 \mathrm{mg}$ of palmitic acid can be determined. 


\subsection{HPLC-ESI-MS/MS Results}

From the chromatogram (Figure S2) and mass spectrum outcomes (Table 6) of HPLCESI-MS/MS, eight tentative compounds are found in E-Anvi. In which, five compounds can be identified as flavonoids including kaempferol-O-galactopyranoside, genistin, quercetin3 -O- $\beta$-d-glucopyranoside, kaempferol 3-O- $\beta$-d-glucopyranoside, eupatilin. The groups of benzophenones (annulatophenonoside), phenolic glycosides (dihydroferulic acid 4-Oglucuronide), proanthocyanidins (prodelphinidin B6) are also detected.

Table 6. Phytocompounds in E-Anvi extract from A. virginicus detected by HPLC-ESI-MS/MS.

\begin{tabular}{|c|c|c|c|c|c|c|c|}
\hline $\begin{array}{l}\text { No. } \\
\text { Signals }\end{array}$ & $\begin{array}{c}\mathrm{RT} \\
(\mathrm{min})\end{array}$ & $\begin{array}{l}{[\mathbf{M}+\mathbf{H}]^{-}} \\
\quad(\mathbf{m} / \mathbf{z})\end{array}$ & $\begin{array}{l}\text { Chemical } \\
\text { Classification }\end{array}$ & $\begin{array}{l}\text { Tentative } \\
\text { Identity }\end{array}$ & $\begin{array}{l}\text { Molecular } \\
\text { Formula }\end{array}$ & $\begin{array}{l}\text { Exact } \\
\text { Mass }\end{array}$ & $\begin{array}{l}\text { Fragmentions } \\
\qquad(\mathrm{m} / \mathrm{z})\end{array}$ \\
\hline 1 & 0.68 & 377.086 & Benzophenones & Annulatophenonoside & $\mathrm{C}_{18} \mathrm{H}_{18} \mathrm{O}_{9}$ & 378.3 & $\begin{array}{l}\text { 89.024(100); 119.086(53); } \\
143.036(45) ; 149.099(28)\end{array}$ \\
\hline 2 & 5.74 & 371.098 & $\begin{array}{l}\text { Phenolic } \\
\text { glycosides }\end{array}$ & $\begin{array}{l}\text { Dihydroferulic acid } \\
\text { 4-O-glucuronide }\end{array}$ & $\mathrm{C}_{16} \mathrm{H}_{20} \mathrm{O}_{10}$ & 372.3 & $\begin{array}{c}231.158(100) ; 243.293(23) ; \\
225.296(19) ; 121.105(14)\end{array}$ \\
\hline 3 & 6.08 & 447.093 & Flavonoids & $\begin{array}{l}\text { Kaempferol-O- } \\
\text { galactopyranoside }\end{array}$ & $\mathrm{C}_{21} \mathrm{H}_{20} \mathrm{O}_{11}$ & 448.4 & $\begin{array}{c}327.154(100) ; 357.141(48) \\
429.155(5) ; 369.242(4)\end{array}$ \\
\hline 4 & 6.35 & 431.098 & Flavonoids & Genistin & $\mathrm{C}_{21} \mathrm{H}_{20} \mathrm{O}_{10}$ & 432.4 & $\begin{array}{c}311.140(100) ; 341.117(6) \\
283.142(2)\end{array}$ \\
\hline 5 & 6.54 & 463.088 & Flavonoids & $\begin{array}{l}\text { Quercetin-3-O- } \beta \text {-d- } \\
\text { glucopyranoside }\end{array}$ & $\mathrm{C}_{21} \mathrm{H}_{20} \mathrm{O}_{12}$ & 464.4 & $\begin{array}{c}445.145(100) ; 343.148(92) \\
427.169(75) ; 373.161(48)\end{array}$ \\
\hline 6 & 6.67 & 447.093 & Flavonoids & $\begin{array}{l}\text { Kaempferol 3-O- } \beta \text {-d- } \\
\text { glucopyranoside }\end{array}$ & $\mathrm{C}_{21} \mathrm{H}_{20} \mathrm{O}_{11}$ & 448.4 & $\begin{array}{c}\text { 285.167(100); 402.158(6); } \\
\text { 428.144(5); 374.128(3) }\end{array}$ \\
\hline 7 & 8.37 & 413.088 & Proanthocyanidins & Prodelphinidin B6 & $\mathrm{C}_{21} \mathrm{H}_{18} \mathrm{O}_{9}$ & 414.4 & $\begin{array}{c}313.135(100) ; 297.155(73) \\
369.145(70) ; 285.154(20)\end{array}$ \\
\hline 8 & 9.71 & 343.082 & Flavonoids & Eupatilin & $\mathrm{C}_{18} \mathrm{H}_{16} \mathrm{O}_{7}$ & 344.3 & 311.153(100) \\
\hline
\end{tabular}

RT, retention time.

\section{Discussion}

In recent years, the influence of oxidative stress on numerous chronic diseases has been proposed though rarely established [13-22]. Thus, a vast number of studies were globally conducted to examine the role of antioxidant agents in several chronic disorders such as cardiovascular diseases, cancer, diabetes, Alzheimer's disease. However, the clinical tests on the human patient have shown failure [31-33]. This unsuccessful result can be explained by selecting only potent antioxidant agents to prevent different targeted diseases [34]. Therefore, in the present study, the simultaneous effects of antioxidant, anti-tyrosinase, anti- $\alpha$-amylase, and cytotoxic potentials were investigated on $A$. virginicus, an invasive weed that was once thought to be of no use.

Basically, the biological activities of plant samples are depended on their chemical composition. Therefore, the detection and identification of phytocompounds are required in the research on plant bioactivity. In the present study, the total phenolic (TPC) and flavonoid (TFC) contents were firstly screened. Among fractional extracts, ethyl acetate contains the highest TPC and TFC. The most abundant compounds identified in the extract belong to flavonoids and flavonoid glycosides. Theoretically, such compounds express a higher affinity to water fraction or butanol fraction. Therefore, previous studies tended to select the polar solvents and extraction protocols such as hexane, ethyl acetate, butanol, $50 \%$ ethanol, and water, which were more effective in flavonoid glycoside extraction, and their solubility in ethyl acetate was rather law [35,36]. In fact, the identification and characterization of phytocompound composition of each plant sample are influenced by various factors such as plant species and extraction methods. The TPC and TFC in ethyl acetate extract were found to be equal or higher than aqueous and butanol extracts in case of several species like Euphorbia splendida [37] or Ziziphus jujube [38]. On the other 
hand, this study used the Soxhlet extraction with organic solvents (methanol and ethyl acetate $2: 8, v / v$ ), which could obtain flavonoid glycoside components. This suggests that the mentioned extraction protocol may be appropriate to extract flavonoid glycosides from A. virginicus sample. However, further extraction and isolation methods should be applied to optimize the purification of potential compounds from this species.

In antioxidants, the potent activities of phenolics and flavonoids such as radical scavenging and metal ion chelation have been widely reported. It can be explained via their specific structure of aromatic ring, and especially the number of hydroxyl $(-\mathrm{OH})$ groups [39-42]. The correlation among TPC, TFC, and antioxidant ability of $A$. virginicus reinforces the above statement (Table 4). Remarkably, the strongest samples of antioxidant activities include the total crude and ethyl acetate extracts, which are recorded to contain high levels of phenolic compounds, particularly flavonoids (Table 1). Notably, the ethyl acetate extract exhibits stronger radical scavenging capacities via ABTS, and DPPH assays and higher reducing power than BHT, a well-known antioxidant agent (Table 2). Hence, the HPLC-ESI-MS/MS method was applied to analyze the chemical profiles in this extract. Accordingly, the ethyl acetate extract is found rich in flavonoid content, which may determine the potent antioxidant ability of this extract (Table 6).

Besides the antioxidant activity, flavonoids in A. virginicus may be a main contributor to anti-tyrosinase ability of the total crude and ethyl acetate extracts in this study (Tables 3, 4 and 6). Previously, flavonoids were recorded having inhibitory effects against tyrosinase through in silico and in vitro screenings [43]. However, unlike the antioxidant capacities, the enzymatic reactions are much more complicated and difficult to predict, which are influenced by various features in chemical structures [44]. For example, the rings A and $\mathrm{C},(-\mathrm{OH})$ substituent at the position of 7 , and the ring $\mathrm{B}$ linked to $(-\mathrm{OH})$ groups at the position of para or para and meta in the flavonoid structures lead to the competitive inhibition against tyrosinase [43]. In the case of anti- $\alpha$-amylase activity, the inhibition may depend on different factors such as the position of $(-\mathrm{OH})$ substituents, methoxy groups, lactone rings, or the interaction between compounds in the mixture [44]. Via the results of $\alpha$-amylase inhibitory assay (Table 3), the hexane extract from $A$. virginicus shows the strongest suppression. Thus, the GC-MS analysis was performed to find out the major compounds involving in the prevention against $\alpha$-amylase in this extract. Among the most dominant compounds, palmitic acid shows the highest peak area and accounts for 0.86 and $0.05 \mathrm{mg}$ per $1 \mathrm{~g}$ of $A$. virginicus dry weight and hexane dried extract, respectively (Table 5), whilst other compounds in Table 5 were neither successfully isolated nor be purchased, thus need further clarification. Notably, palmitic acid is an acknowledged $\alpha$-amylase inhibitor [45-47], thus it was used as a positive control in this study. Remarkably, the hexane extract reveals over twice stronger inhibitory effect than palmitic acid by comparing their $\mathrm{IC}_{50}$ values. Because palmitic acid is a major compound (Table 5) in the plant, it is suggested that this compound may play an important role in the biological potential of the invasive weed, beside the $\alpha$-amylase inhibitory effect as shown in this study. The hexane extract's activity may be strengthened due to the interaction between four dominant compounds consisting of palmitic acid, $\gamma$-sitosterol, phytol, and 8-methyl-1-undecene (Table 5). In which, $\gamma$-sitosterol is also a high potential anti-diabetes substance, which has been affirmed through in vitro and in vivo tests on rats in recent studies [48]. Therefore, this compound may play an influential role in the anti- $\alpha$-amylase ability of the hexane extract.

The detected flavonoids in the $A$. virginicus's total crude and ethyl acetate extracts may be also the primary agents for the cytotoxic activities against K562 and Meg-01 cell lines. According to the previous studies including laboratory bioassays, epidemiological investigations, and clinical trials, flavonoids have shown important chemotherapy roles for cancer. The anticancer property of flavonoids has been comprehensively explained through various biological pathways such as antioxidants, enzymatic activities, genetic factors, and cell-related mechanisms, or synergic effects of these mentioned factors [49]. Remarkably, the antioxidant activity of flavonoids is closely associated with anticancer regulation [50]. Meanwhile, phytoflavonoids are not harmful to normal myeloid, peripheral blood, and 
epithelial cell lines [51]. In our research, we also find a strong correlation between total phenolics and flavonoids, antioxidant and cytotoxic capacities in the ethyl acetate extract (Table 4). On the other hand, the hexane extract's cytotoxic activity against Meg-01 cell line may be due to the presence of phytol and $\gamma$-sitosterol or the combined influence of the found compounds in this extract (Figure 3 and Table 5). Particularly, phytol is a popular anticancer agent, which has been mentioned in numerous recent studies. The inhibition of this compound on different types of cancer cells and relevant modes of action have been globally published [52-57]. Whilst $\gamma$-sitosterol has been also known to be an antitumor agent, its specific mechanism has been reported in other studies [58,59].

In addition to finding out potential therapeutic properties and phytocompounds, the specific direction of developing natural-based drugs is essentially considered to come up with the most effective approach [60]. For example, clinical tests through randomized controlled trials are required before the products are registered as drugs. One of the critical factors is that natural products must satisfy the safety requirements. In fact, some of them have shown hepatotoxicity with high application dose in clinical trials on humans [60-62]. Therefore, although numerous plant products have proven their potentials for therapeutic uses, very few of them have been officially registered and widely applied. An effective approach can be addressed such as investigating the biological properties of folk medicines and traditional food stuffs. Ginger shell (Alpinia zerumbet) can be an example, which is considered as a significant contributor to human longevity in Japanese Okinawa $[63,64]$. This plant species is popularly used with even no clinical data available. However, the overuse of these natural plants also leads to the loss of biodiversity [60]. Therefore, changing the conventional objects to other available resources, especially problematic invasive species, is a prospective direction. The exploitation of invasive weed for medicinal purposes can simultaneously solve the problems in biodiversity conservation and sustainable development.

In general, the invasive weed $A$. virginicus shows the potential for antioxidant, antidiabetes, anti-skin aging, and anti-CML properties via in vitro approaches. Therefore, in vivo tests and clinical trials should be further performed to develop novel natural-based drugs. Additionally, the screening results by GC-MS (Table 5) and HPLC-ESI-MS/MS (Table 6) indicate the most dominant compounds including palmitic acid, $\gamma$-sitosterol, phytol, and 8-methyl-1-undecene, flavonoids, and flavonoid glycosides, which might be the main contributors to the biological activities of this plant. Based on that, the research on confirmation of their role in biological and pharmaceutical properties of $A$. virginicus should be conducted. Furthermore, the quantification of bioactive compounds in mixtures and extracts showing the potent activity should be also carried out. Palmitic acid has been reported as an inhibitor for anti-diabetes [45-47], phytol and $\gamma$-sitosterol are popularly known as anticancer agents [52-59]. While flavonoids and flavonoid glycosides can be used as antioxidant agents and applied in treatment for numerous diseases [39-43,49]. The quantification of dominant and specific bioactive compounds should use advantage analytical instruments such as LC-MS and LC-ESI-MS/MS rather than the estimation of total flavonoids and phenols and quantification by only GC-MS. Future studies focusing on isolation, purification, and quantification of bioactive compounds from $A$. virginicus should be performed to explore the medicinal and pharmaceutical potential of this invasive species. This could help farmers in developing countries to improve their income from the utilization of this harmful weed as a source of antioxidants, anti-skin aging, anti-diabetes, and anticancer.

\section{Materials and Methods}

4.1. Materials

\subsubsection{Chemicals and Cell Lines}

Extraction solvents including methanol, hexane, ethyl acetate, and butanol were purchased from Junsei Chemical Co., Ltd., Tokyo, Japan. Standards including gallic acid, rutin, butylated hydroxytoluene (BHT), kojic acid were purchased from Kanto Chem- 
ical Co., Inc., Tokyo, Japan. Palmitic acid was obtained from FUJIFILM Wako Pure Chemical Corporation.

Chemicals including sodium hypochlorite $(\mathrm{NaClO})$, Folin-Ciocalteu's reagent, sodium carbonate $\left(\mathrm{Na}_{2} \mathrm{CO}_{3}\right)$, aluminum chloride $\left(\mathrm{AlCl}_{3}\right), 2,2^{\prime}$-azinobis-(3-ethylbenzothiazoline6-sulfonic acid) (ABTS), potassium persulfate $\left(\mathrm{K}_{2} \mathrm{~S}_{2} \mathrm{O}_{8}\right)$, 2,2-diphenyl-1-picrylhydrazyl (DPPH), sodium acetate $\left(\mathrm{CH}_{3} \mathrm{COONa}\right), \beta$-carotene, chloroform, linoleic acid, tween 40 , dipotassium phosphate $\left(\mathrm{K}_{2} \mathrm{HPO}_{4}\right)$, monopotassium phosphate $\left(\mathrm{KH}_{2} \mathrm{PO}_{4}\right)$, potassium ferricyanide $\left(\mathrm{K}_{3}\left[\mathrm{Fe}(\mathrm{CN})_{6}\right]\right)$, trichloro acetic acid $\left(\mathrm{CCl}_{3} \mathrm{COOH}\right)$, ferric chloride $\left(\mathrm{FeCl}_{3}\right)$, dimethyl sulfoxide (DMSO), monosodium phosphate $\left(\mathrm{NaH}_{2} \mathrm{PO}_{4}\right)$, sodium chloride $(\mathrm{NaCl})$, hydrochloric acid $(\mathrm{HCl})$ were obtained from Kanto Chemical Co., Inc., Tokyo, Japan. While tyrosinase, L-tyrosine, $\alpha$-amylase, starch, iodine, 3-(4,5-dimethylthiazolyl)2,5-diphenyltetrazolium bromide (MTT), Iscove's Modified Dulbecco's Medium (IMDM), and cell lysis buffer were purchased from Sigma-Aldrich, St. Louis, MO, USA.

K562 and Meg-01 cell lines were obtained from American Type Culture Collection (ATCC), Virginia, United States.

\subsubsection{Plant Materials}

The aerial plant parts of $A$. virginicus were collected in fields affiliated to HigashiHiroshima Campus, Hiroshima University, Hiroshima, Japan in October 2019. The species' identification was primarily based on the publication of European and Mediterranean Plant Protection Organization [2], available database of Missouri Botanical Garden, United States [65], the National Institute for Environmental Studies, Japan [66], and the book entitled: "Invasive Weed" published by Japan Livestock Technology Association [67]. The specimen with voucher number of Anvi-J2019 was preserved at the Laboratory of Plant Physiology and Biochemistry, Graduate School of Advanced Science and Engineering, Hiroshima University, Japan.

\subsection{Sample Preparation and Extraction}

Impurities were removed from $A$. virginicus aerial plant parts by water and $0.5 \%$ $\mathrm{NaClO}$ before being dried by an oven at $40{ }^{\circ} \mathrm{C}$ for 1 week. Fine powder was made by grinding the dried samples. Subsequently, the obtained powder (10 g) was subjected to a Soxhlet extractor consisting of extraction chamber and condenser (Climbing Co., Ltd., Fukuoka, Japan) connecting to a mantle heater (Daika Denki Co., Ltd., Osaka, Japan). An aliquot $(400 \mathrm{~mL})$ of methanol and ethyl acetate $(2: 8, v / v)$ mixture was the extraction solvent. After $5 \mathrm{~h}$, the obtained extract was filtrated and concentrated by removing solvent with a rotary evaporator (Nihon Buchi K.K., Tokyo, Japan) to yield the crude extract (TAnvi). After that, the dried T-Anvi was mixed with distilled water $(50 \mathrm{~mL})$ and subjected to liquid-liquid phase $(1: 1, v / v)$ extraction with hexane, followed by ethyl acetate, and butanol, respectively. With each extraction solvent, the aqueous phase was returned to the separatory funnel, and the entire process was repeated to collect the maximum amount of target compounds. Finally, the collected extracts were filtered and evaporated at $50{ }^{\circ} \mathrm{C}$ under vacuum to acquire the dried hexane (H-Anvi), ethyl acetate (E-Anvi), and butanol (B-Anvi) extracts, respectively. The remaining water residue was also concentrated to attain the water extract (W-Anvi).

\subsection{Total Phenolic (TPC) and Flavonoid (TFC) Contents}

The Folin-Ciocalteu method was applied to determine the TPC of extracts from A. virginicus [68]. Briefly, the mixture including $20 \mu \mathrm{L}$ of sample (in methanol), $100 \mu \mathrm{L}$ of $10 \%$ Folin-Ciocalteu solution and $80 \mu \mathrm{L}$ of $7.5 \% \mathrm{Na}_{2} \mathrm{CO}_{3}$ was incubated at room temperature for $30 \mathrm{~min}$. The result was recorded at $765 \mathrm{~nm}$ and expressed as milligrams of gallic acid equivalent per one gram of sample dry weight (mg GAE/g DW).

The aluminum chloride colorimetric method represented by Tuyen et al. [69] was applied to evaluate the TFC of extracts from A. virginicus with a slight alteration. In detail, the incubated reaction of $50 \mu \mathrm{L}$ of sample (in methanol) and an equal volume of $2 \%$ 
$\mathrm{AlCl}_{3}$ was carried out. The result was measured after $15 \mathrm{~min}$ at $430 \mathrm{~nm}$ and presented as milligrams of rutin equivalent per one gram of sample dry weight (mg RE/g DW).

\subsection{Antioxidant Activity}

\subsubsection{ABTS Cation Decolorization Assay}

The method was presented by Pellegrini et al. [70]. In advance of colorimetric reaction, the ABTS working solution was prepared in the course of incubation for the mixture consisting of $7 \mathrm{mM}$ ABTS and $2.45 \mathrm{mM} \mathrm{K} \mathrm{S}_{2} \mathrm{O}_{8}(1: 1, v / v)$ for $16 \mathrm{~h}$ without light at $25^{\circ} \mathrm{C}$. Methanol was then added to achieve the targeted absorbance $(0.65-0.75)$ at $734 \mathrm{~nm}$. The decolorization ability was evaluated by pipetting sample/or control (in methanol) into ABTS working solution $(1: 9, v / v)$ with a total volume of $200 \mu \mathrm{L}$ of combination. The reaction was incubated in darkness for $20 \mathrm{~min}$. The inhibition percentage was measured as decreased absorbance over the control at $734 \mathrm{~nm}$.

\subsubsection{DPPH Radical Scavenging Assay}

Based on the protocol demonstrated by Elzaawely and Tawata [71], the discoloration ability of $80 \mu \mathrm{L}$ of methanolic sample/or control on $40 \mu \mathrm{L}$ of DPPH solution $(0.2 \mathrm{mg} / \mathrm{mL})$ in addition to $80 \mu \mathrm{L}$ of acetate buffer $(0.1 \mathrm{M}, \mathrm{pH}=5.5)$ was observed. The absorbance was read after $20 \mathrm{~min}$ of incubation at $25^{\circ} \mathrm{C}$ with an avoidance of direct light. The inhibition was recorded as percentage of decreased absorbance over the control at $517 \mathrm{~nm}$.

The anti-radical (ABTS and DPPH) ability was evaluated following the below formula:

$$
\text { Anti-radical ability }(\%)=(C-S) / C \times 100
$$

C: Absorbance of reaction with negative control (methanol) after subtracting control's blank (without radical solution), S: Absorbance of reaction with sample/or positive control (BHT) after subtracting sample's blank (without radical solution).

Different concentrations of sample/or control were tested to establish a dose-dependent curve (linear equation). Based on the equation, the required concentration of samples/or control for inhibiting $50 \%$ of radicals ( $\mathrm{IC}_{50}$ values) was obtained. Lower $\mathrm{IC}_{50}$ value means stronger inhibition.

\subsection{3. $\beta$-Carotene Bleaching Assay}

The process was performed according to the previous report of Tuyen et al. [69]. Firstly, the combination containing $\beta$-carotene $(200 \mu \mathrm{g})$, chloroform $(1 \mathrm{~mL})$, linoleic acid $(20 \mu \mathrm{L})$, and tween $40(200 \mathrm{mg})$, respectively was prepared. The obtained solution was then concentrated under vacuum at $40^{\circ} \mathrm{C}$ by a rotary evaporator. Subsequently, fifty milliliters of oxygenated water were slowly mixed and shaken to generate a stable emulsion. The lipid peroxidation inhibition (LPI) was evaluated by adding methanolic sample/or control $(500 \mu \mathrm{g} / \mathrm{mL})$ to the working emulsion $(1: 8, v / v)$ in a total of $225 \mu \mathrm{L}$ of reaction solution. Similar to anti-radical assay, methanol and BHT were used as controls. The absorbance readings were recorded every $15 \mathrm{~min}$ for a total of 13 times at $492 \mathrm{~nm}$. The lipid peroxidation inhibition (LPI) was measured as follows:

$$
\operatorname{LPI}(\%)=\mathrm{A}_{180} / \mathrm{A}_{0} \times 100
$$

$\mathrm{A}_{180}$ : absorbance of reaction at the $180^{\text {th }} \mathrm{min}, \mathrm{A}_{0}$ : absorbance of reaction at the beginning time point.

\subsubsection{Reducing Power Assay}

We followed the same method applied in the study of Quan et al. [44]. For preparation, the solutions including phosphate buffer $(0.2 \mathrm{M}, \mathrm{pH}=6.6)$; potassium ferricyanide $(1 \mathrm{~g} / 100 \mathrm{~mL})$; trichloro acetic acid $(10 \mathrm{~g} / 100 \mathrm{~mL})$; ferric chloride $(0.01 \mathrm{~g} / 10 \mathrm{~mL})$ were prepared in distilled water. The first step was to incubate the mixture of methanolic sample/or control $(0.1 \mathrm{~mL})$, phosphate buffer $(0.25 \mathrm{~mL})$, and potassium ferricyanide solution 
$(0.25 \mathrm{~mL})$ for $30 \mathrm{~min}$ at $50{ }^{\circ} \mathrm{C}$. After that, trichloro acetic acid solution $(0.25 \mathrm{~mL})$ was added and centrifuged for $10 \mathrm{~min}$ at $4000 \mathrm{rpm}$. Subsequently, the supernatant $(100 \mu \mathrm{L})$ was mixed with $100 \mu \mathrm{L}$ of distilled water, followed by $20 \mu \mathrm{L}$ of ferric chloride solution. The absorbance of final solution was read at $700 \mathrm{~nm}$. Methanol and BHT were used as negative and positive controls, respectively. Five concentrations $(10,62.5,125,250,500 \mu \mathrm{g} / \mathrm{mL})$ of sample/or control were examined to build the dose-responding curves. From the curve, $\mathrm{IC}_{50}$ values were calculated to compare between samples. In which, $\mathrm{IC}_{50}$ value was the required concentration to reach the absorbance of 0.5 .

\subsection{Enzymatic Inhibitory Assays \\ 4.5.1. Tyrosinase Inhibition}

The assay components included potassium phosphate buffer $(20 \mathrm{mM}, \mathrm{pH}=6.8)$, tyrosinase (500 units / $\mathrm{mL}$ in buffer), L-tyrosine substrate ( $2 \mathrm{mM}$ in distilled water) solutions. Samples/or controls were prepared in DMSO. At the beginning, $20 \mu \mathrm{L}$ of sample/or control and $20 \mu \mathrm{L}$ of enzyme solution were homogenized in $120 \mu \mathrm{L}$ of buffer. The combination was incubated at $25^{\circ} \mathrm{C}$ for $5 \mathrm{~min}$. After that, the enzymatic reaction was inaugurated by supplying $50 \mu \mathrm{L}$ of L-tyrosine solution. After $10 \mathrm{~min}$ of incubation at the same condition, the final solution's absorbance was recorded at $470 \mathrm{~nm}$ [72]. DMSO and kojic acid were used as negative control and standard inhibitor, respectively. The inhibitory activity was calculated using the formula as follows:

$$
\% \text { inhibition }=(\mathrm{C}-\mathrm{S}) / \mathrm{C} \times 100
$$

C: Absorbance of reaction with DMSO after subtracting control's blank (without enzymatic reaction on substrate), S: Absorbance of reaction with sample/or inhibitor after subtracting sample's blank (without enzymatic reaction on substrate).

$\mathrm{IC}_{50}$ values of samples against tyrosinase were recorded in the same method with anti-radical assay.

\subsection{2. $\alpha$-Amylase Inhibition}

The in vitro $\alpha$-amylase inhibition assay was determined according to the method reported by Quan et al. [44]. For preparation, phosphate buffer saline (0.2 M, pH =6.9) and $\alpha$-amylase ( 5 units $/ \mathrm{mL}$ in buffer), starch substrate $(0.5 \%$ in distilled water), iodine ( $0.25 \mathrm{mM}$ in distilled water) solutions were included. Samples/or controls were prepared in the buffer. Initially, the incubation of $40 \mu \mathrm{L}$ of mixture including sample/or control and prepared enzyme $(1: 1, v / v)$ was conducted at $37^{\circ} \mathrm{C}$ for $9 \mathrm{~min}$. The enzymatic reaction on substrate was generated by providing $30 \mu \mathrm{L}$ of starch working solution. The reaction was continued at $37^{\circ} \mathrm{C}$ for 7 min before stopping by $20 \mu \mathrm{L}$ of $\mathrm{HCl}(1 \mathrm{M})$. To detect the remaining amount of substrate in the final solution, one hundred microliters of prepared iodine solution were added. The final reaction mixture was recorded at $565 \mathrm{~nm}$. DMSO (50\% in buffer) was negative control and palmitic acid was standard inhibitor. The inhibition percentage was determined as follows:

$$
\% \text { inhibition }=\mathrm{S} / \mathrm{C} \times 100
$$

S: Absorbance of reaction with sample/or inhibitor after subtracting an absorbance of the enzymatic reaction without inhibitor, $C$ : Absorbance of reaction without sample/or control and enzyme after subtracting an absorbance of the enzymatic reaction without inhibitors.

Similar to anti-radical and tyrosinase assays, $\mathrm{IC}_{50}$ values were applied to compare inhibitory activities among samples.

\subsection{Cytotoxic Activity against K562 and Meg-01 Cell Lines}

The cell growth rate was determined through the cell metabolic activity applying MTT assay. The cell culture media was IMDM containing fetal bovine serum (10\%), Lglutamine $(5 \mathrm{mM})$, Penicillin $(100 \mathrm{IU} / \mathrm{mL})$, and Streptomycin $(100 \mu \mathrm{g} / \mathrm{mL})$. Samples were 
prepared in $0.1 \%$ DMSO (in culture media). In each plate's well, the cells $\left(5 \times 10^{3}\right)$ were seeded in culture media $(90 \mu \mathrm{L})$ and placed in an incubator (Thermo Fisher Scientific, Waltham, United States) for $24 \mathrm{~h}$ at $37{ }^{\circ} \mathrm{C}$ with $\mathrm{CO}_{2} 5 \%$. After that, ten microliters of sample were pipetted to each well. After $40 \mathrm{~h}$, ten microliters of MTT solution $(5 \mathrm{mg} / \mathrm{mL})$ were supplied. The cells were continuously incubated at $37^{\circ} \mathrm{C}$ for $4 \mathrm{~h}$. Subsequently, one hundred microliters of cell lysis buffer $(10 \%$ SDS in $0.01 \mathrm{M} \mathrm{HCl})$ were added to each well. The cell expansion was observed using an inverted microscope (LabX, Midland, Canada). The absorbance at $595 \mathrm{~nm}$ was applied to determine the cell viability in value. The negative control was conducted by adding 10 microliters of culture media instead of sample.

$$
\% \text { inhibition }=(C-S) / C \times 100
$$

C: Absorbance of the reaction with negative control, S: Absorbance of reaction with sample. The dose-response curves and $\mathrm{IC}_{50}$ values of samples against K562 and Meg-01 cell lines were established to compare between samples.

\subsection{Identification of Phytochemical Component}

\subsubsection{GC-MS}

The phytochemical components of the hexane extract (H-Anvi) were analyzed by GC-MS system (JMS-T100 GCV, JEOL Ltd., Tokyo, Japan). The column (DB-5MS, $30 \mathrm{~m} \times 0.25 \mathrm{~mm}$ I.D. $\times 0.25 \mu \mathrm{m}$ film thickness) (Agilent Technologies, J\&W Scientific Products, Folsom, United States) was connected to the system. The injection was performed by the system equipped with an autosampler. Sample $(2 \mathrm{mg} / \mathrm{mL})$ was prepared for measurement. The split ratio of 5:1 was applied for the carrier gas helium. The GC oven's temperature was scheduled as follows:

(1) Initial temperature: $50^{\circ} \mathrm{C}$ (without holding),

(2) Rushing temperature: $10^{\circ} \mathrm{C} / \mathrm{min}$ for $30 \mathrm{~min}$ and $20 \mathrm{~min}$ in maintenance,

(3) Injector and detector temperatures: $300^{\circ} \mathrm{C}$ and $320^{\circ} \mathrm{C}$, respectively.

The mass was scanned in the range of 29 to $800 \mathrm{amu}$. The results of chromatogram, mass spectrum (electron ionization), linear retention index (LRI), and Kovats index (KI) of each detected compound were collected. The outcomes were compared to the standard sources comprising the library of JEOL's GC-MS Mass Center System Version 2.65a, and the online database of National Center for Biotechnology Information, U.S. National Library of Medicine, Bethesda MD, USA (Pubchem-https://pubchem.ncbi.nlm.nih.gov), and the National Institute of Standards and Technology, U.S. Department of Commerce (NISThttps://webbook.nist.gov). Based on the GC-MS results, palmitic acid was detected as the most dominant compound in H-Anvi. Therefore, a calibration curve applying different concentrations of palmitic acid standard $(0.1,0.5$, and $1 \mathrm{mg} / \mathrm{mL})$ was established to determine the content of palmitic acid in A. virginicus. The result was expressed as milligrams per one gram of sample dry weight (mg/g DW).

\subsubsection{HPLC-ESI-MS/MS}

The phytochemicals of the ethyl acetate extract (E-Anvi) were identified based on the HPLC-ESI-MS/MS method. In particular, the HPLC-ESI-MS/MS system was equipped with LTQ Orbitrap XL mass spectrometers (Thermo Fisher Scientific, Waltham, United States) and an electrospray ionization (ESI) source. For analysis, sample $(2 \mathrm{mg} / \mathrm{mL})$ with a volume of $3.0 \mu \mathrm{L}$ was injected into the XBridge ${ }^{\circledR}$ Shield RP18 $(5 \mu \mathrm{m}, 2.1 \times 100 \mathrm{~mm})$ column, which maintained the temperature at $25^{\circ} \mathrm{C}$. The gradient model with 2 solvents was set up as follows: solvent $\mathrm{A}$ was $0.1 \%$ formic acid in water, solvent $\mathrm{B}$ was pure acetonitrile. The gradient program was: $95 \% \mathrm{~A}$ and $5 \% \mathrm{~B}$ over $0-2 \mathrm{~min}$, then changed to $30 \% \mathrm{~A}$ and $70 \%$ B over 2-12 min, followed by $0 \%$ A and 100\% B over 12-22 min. From 22-34 min, the mobile phase was subjected to the initial condition of $95 \% \mathrm{~A}$ and $5 \% \mathrm{~B}$. The flow rate was $400 \mu \mathrm{L} / \mathrm{min}$. For mass scanning, a negative FTMS mode with the range from 100 to $700 \mathrm{~m} / \mathrm{z}$ was applied. The online database (Pubchem, National Center for Biotechnology 
Information, U.S. National Library of Medicine, Bethesda MD, USA) was used for reference to MS/MS spectra.

\subsection{Data Analysis}

All bioassays were tested with three replications. One-way ANOVA statistical method in Minitab software version 16.2.3 was applied to analyze the raw data. The statistical data including means, standard deviations (SD), and grouping information were obtained and expressed as final outcomes. Various groups indicate significant differences under Turkey's test at the confidence level of 95\%. Pearson's correlation coefficients between total phenolic and flavonoid contents, antioxidant, anti-tyrosinase, $\alpha$-amylase, and cytotoxic activities of extracts from $A$. virginicus were evaluated using the same software.

\section{Conclusions}

This is the first investigation of the biological properties of the invasive weed A. virginicus including antioxidants, anti- $\alpha$-amylase, and anti-tyrosinase abilities, and cytotoxicity against CML cell lines. The results show that the ethyl acetate extract from A. virginicus exhibits the highest antioxidant activity via ABTS, DPPH, reducing power assays, and $\beta$ carotene bleaching models. In addition, this extract reveals potential anti-tyrosinase capacity and potent cytotoxicity against K562 and Meg-01 cell lines. Meanwhile, the hexane extract displays strong $\alpha$-amylase and Meg-01 inhibitory effects. The chemical analysis results indicate that $A$. virginicus aerial parts are rich in flavonoids, palmitic acid, phytol, and $\gamma$-sitosterol, which may principally play a vital role in biological activities of the respective extracts. The finding suggests that $A$. virginicus is a promising source of antioxidant, antidiabetic, anti-tyrosinase, and antitumor agents. Further in vivo and clinical tests should be performed to confirm and develop the natural functional products from A. virginicus for pharmaceutical purposes.

Supplementary Materials: The following are available online at https:/ /www.mdpi.com/2223-774 7/10/1/69/s1, Figure S1: GC-MS chromatogram of H-Anvi extract, Figure S2: HPLC chromatogram of E-Anvi extract.

Author Contributions: Conceptualization, N.V.Q., A.T., R.T. and T.D.X.; data curation, L.H.A., V.Q.L.; formal analysis, L.H.A.; methodology, N.V.Q., V.Q.L., A.T. and T.D.X.; project administration, A.T. and T.D.X.; supervision, N.V.Q., A.T and T.D.X.; visualization, N.V.Q., A.T., R.T. and T.D.X.; writingoriginal draft preparation, L.H.A.; writing-review and editing, L.H.A., N.V.Q., V.Q.L., Y.I., A.T., R.T. and T.D.X. All authors have read and agreed to the published version of the manuscript.

Funding: This research received no external funding.

Institutional Review Board Statement: Not applicable.

Informed Consent Statement: Not applicable.

Data Availability Statement: All data are presented in the article and Supplementary Materials.

Acknowledgments: The authors are grateful to the Ministry of Education, Culture, Sports, Science, and Technology (MEXT), Japan to provide La Hoang Anh a scholarship.

Conflicts of Interest: The authors declare no conflict of interest.

\section{References}

1. Campbell, C. Andropogon. In Flora of North America North of Mexico, Volume 25: Magnoliophyta: Commelinidae (in Part): Poaceae, Part 2; Flora of North America Editorial Committee, Ed.; Oxford University Press: New York, NY, USA, 2003; Volume 25, p. 814.

2. European and Mediterranean Plant Protection Organization. Andropogon virginicus L. Bull. OEPP/EPPO Bull. 2019, 49, 61-66. [CrossRef]

3. U.S. Department of Agriculture, Forest Service, Rocky Mountain Research Station, Fire Sciences Laboratory (Producer). Available online: https://www.fs.fed.us/database/feis/plants/graminoid/andvir/all.html (accessed on 20 October 2020).

4. CABI-Invasive Species Compendium. Available online: http://www.cabi.org/isc/datasheet/5286 (accessed on 14 October 2020). 
5. US Fish and Wildlife Service, Conserving the Nature of America. Available online: https://ecos.fws.gov/speciesProfile/profile/ speciesProfile.action?spcode=Q38V (accessed on 20 October 2020).

6. Weeds of Australia-Biosecurity Queensland Edition Fact Sheet, Andropogon virginicus. Available online: https://keyserver. lucidcentral.org/weeds/data/media/Html/andropogon_virginicus.pdf (accessed on 20 October 2020).

7. Balandier, P.; Collet, C.; Miller, J.H.; Reynolds, P.E.; Zedaker, S.M. Designing forest vegetation management strategies based on the mechanisms and dynamics of crop tree competition by neighbouring vegetation. Forestry 2006, 79, 3-27. [CrossRef]

8. Xu, D.P.; Li, Y.; Meng, X.; Zhou, T.; Zhou, Y.; Zheng, J.; Zhang, J.J.; Li, H.B. Natural antioxidants in foods and medicinal plants: Extraction, assessment and resources. Int. J. Mol. Sci. 2017, 18, 96. [CrossRef] [PubMed]

9. Collins, T. Acute and chronic inflammation. In Pathologic Basis of Disease; Cotran, R.S., Kumar, V., Collins, T., Eds.; WB Saunders: Philadelphia, PA, USA, 1999; pp. 50-88.

10. Anderson, M.T.; Staal, F.J.T.; Gitler, C.; Herzenberg, L.A.; Herzenberg, L.A. Separation of oxidant initiated and redox-regulated steps in the NF-kB signal transduction pathway. Proc. Natl. Acad. Sci. USA 1994, 91, 11527-11531. [CrossRef]

11. Flohe, L.; Brigelius-Flohe, R.; Saliou, C.; Traber, M.G.; Packer, L. Redox regulation of NF-кB activation. Free Radic. Biol. Med. 1997, 22, 1115-1126. [CrossRef]

12. Biswas, S.K.; de Faria, J.B.L. Which comes first: Renal inflammation or oxidative stress in spontaneously hypertensive rats? Free Radic. Res. 2007, 41, 216-224. [CrossRef]

13. Ambade, A.; Mandrekar, P. Oxidative stress and inflammation: Essential partners in alcoholic liver disease. Int. J. Hepatol. 2012, 2012, 853175. [CrossRef]

14. Cachofeiro, V.; Goicochea, M.; de Vinuesa, S.D.; Oubina, P.; Lahera, V.; Luno, J. Oxidative stress and inflammation, a link between chronic kidney disease and cardiovascular disease. Kidney Int. Suppl. 2008, 111, S4-S9. [CrossRef]

15. Tucker, P.S.; Scanlan, A.T.; Dalbo, V.J. Chronic kidney disease influences multiple systems: Describing the relationship between oxidative stress, inflammation, kidney damage, and concomitant disease. Oxid. Med. Cell. Longev. 2015, 2015, 806358. [CrossRef]

16. Sies, H. Introductory remarks. In Oxidative Stress; Sies, H., Ed.; Academic Press: Orlando, FL, USA, $1985 ;$ pp. 1-7.

17. Halliwell, B.; Gutteridge, J.M.C. Free Radicals in Biology and Medicine, 3rd ed.; Oxford University Press: London, UK, 1999.

18. Biswas, S.K.; de Faria, J.B.L. Hypertension induces oxidative stress but not macrophage infiltration in the kidney in the early stage of experimental diabetes mellitus. Am. J. Nephrol. 2006, 26, 415-422. [CrossRef]

19. Biswas, S.K.; Peixoto, E.B.; Souza, D.S.; Lopes de Faria, J.B. Hypertension increases pro-oxidant generation and decreases antioxidant defense in the kidney in early diabetes. Am. J. Nephrol. 2008, 28, 133-142. [CrossRef]

20. Halliwell. Oxidative stress and neurodegeneration: Where are we now? J. Neurochem. 2006, 97, 1634-1658. [CrossRef]

21. Onyango, I.G. Mitochondrial dysfunction and oxidative stress in Parkinson's disease. Neurochem. Res. 2008, 33, 589-597. [CrossRef] [PubMed]

22. Hald, A.; Van Beek, J.; Lotharius, J. Inflammation in Parkinson's disease: Causative or epiphenomenal? Subcell. Biochem. 2007, 42, 249-279. [PubMed]

23. Tarling, C.A.; Woods, K.; Zhang, R.; Brastianos, H.C.; Brayer, G.D.; Andersen, R.J.; Withers, S.G. The search for novel human pancreatic $\alpha$-amylase inhibitors: High-throughput screening of terrestrial and marine natural product extracts. ChemBioChem 2008, 9, 433-438. [CrossRef] [PubMed]

24. Linda, G.H. Dermatological complications of obesity. Am. J. Clin. Dermatol. 2002, 3, 497-506. [CrossRef]

25. Demirseren, D.D.; Emre, S.; Akoglu, G.; Arpac1, D.; Arman, A.; Metin, A.; Cakır, B. Relationship between skin diseases and extracutaneous complications of diabetes mellitus: Clinical analysis of 750 patients. Am. J. Clin. Dermatol. 2014, 15, 65-70. [CrossRef]

26. Klein, E.; Ben-Bassat, H.; Neumann, H.; Ralph, P.; Zeuthen, J.; Polliack, A.; Vanky, F. Properties of the K562 cell line, derived from a patient with chronnic myeloid leukemia. Int. J. Cancer 1976, 18, 421-431. [CrossRef]

27. NIH—National Cancer Institute. Available online: https://www.cancer.gov/publications/dictionaries/cancer-terms/def/whiteblood-cell?fbclid=IwAR1Jr1RfMklHWtlLj2eQ_HdJp9xY6-h8OQHhYkg2fnQWBeDLJbzscm9tLO8 (accessed on 20 October 2020).

28. Koeffler, H.P.; Golde, D.W. Human myeloid leukemia cell lines: A review. Blood 1980, 56, 344-350. [CrossRef]

29. Takeuchi, K.; Ogura, M.; Saito, H.; Satoh, M.; Takeuchi, M. Production of platelet-like particles by a human megakaryoblastic leukemia cell line (Meg-01). Exp. Cell Res. 1991, 193, 223-226. [CrossRef]

30. Ogura, M.; Morishima, Y.; Ohno, R.; Kato, Y.; Hirabayashi, N.; Nagura, H.; Saito, H. Establishment of a novel human megakaryoblastic leukemia cell line, MEG-01, with positive Philadelphia chromosome. Blood 1985, 66, 1384-1392. [CrossRef] [PubMed]

31. Bjelakovic, G.; Nikolova, D.; Gluud, L.L.; Simonetti, R.G.; Gluud, C. Mortality in randomized trials of antioxidant supplements for primary and secondary prevention: Systematic review and meta-analysis. JAMA 2007, 297, 842-857. [CrossRef]

32. Zhang, S.M.; Cook, N.R.; Albert, C.M.; Gaziano, J.M.; Buring, J.E.; Manson, J.E. Effect of combined folic acid, vitamin B6, and vitamin B12 on cancer risk in women: A randomized trial. JAMA 2008, 300, 2012-2021. [CrossRef] [PubMed]

33. Sesso, H.D.; Buring, J.E.; Christen, W.G.; Kurth, T.; Belanger, C.; MacFadyen, J.; Bubes, V.; Manson, J.E.; Glynn, R.J.; Gaziano, J.M. Vitamins $\mathrm{E}$ and $\mathrm{C}$ in the prevention of cardiovascular disease in men: The physicians' health study II randomized controlled trial. JAMA 2008, 300, 2123-2133. [CrossRef] [PubMed]

34. Biswas, S.K. Does the interdependence between oxidative stress and inflammation explain the antioxidant paradox? Oxid. Med. Cell. Longev. 2016, 2016, 5698931. [CrossRef] 
35. Thavamoney, N.; Sivanadian, L.; Tee, L.H.; Khoo, H.E.; Prasad, K.N.; Kong, K.W. Extraction and recovery of phytochemical components and antioxidative properties in fruit parts of Dacryodes rostrata influenced by different solvents. J. Food Sci. Technol. 2018, 55, 2523-2532. [CrossRef]

36. Tagousop, C.N.; Tamokou, J.-D.-D.; Ekom, S.E.; Ngnokam, D.; Voutquenne-Nazabadioko, L. Antimicrobial activities of flavonoid glycosides from Graptophyllum grandulosum and their mechanism of antibacterial action. BMC Complement. Altern. Med. 2018, 18, 252. [CrossRef]

37. Kefayati, Z.; Motamed, S.M.; Shojaii, A.; Noori, M.; Ghods, R. Antioxidant activity and phenolic and flavonoid contents of the extract and subfractions of Euphorbia splendida Mobayen. Pharmacogn. Res. 2017, 9, 362-365. [CrossRef]

38. Al-Saeedi, A.H.; Al-Ghafri, M.T.H.; Hossain, M.A. Comparative evaluation of total phenols, flavonoids content and antioxidant potential of leaf and fruit extracts of Omani Ziziphus jujuba L. Pac. Sci. Rev. A Nat. Sci. Eng. 2016, 18, 78-83. [CrossRef]

39. Soobrattee, M.A.; Neergheen, V.S.; Luximon-Ramma, A.; Aruoma, O.I.; Bahorun, T. Phenolics as potential antioxidant therapeutic agents: Mechanism and actions. Mutat. Res. Fundam. Mol. Mech. Mutagen. 2005, 579, 200-213. [CrossRef]

40. Kelly, E.H.; Anthony, R.T.; Dennis, J.B. Flavonoid antioxidants: Chemistry, metabolism and structure-activity relationships. J. Nutr. Biochem. 2002, 13, 572-584. [CrossRef]

41. Pandey, A.K.; Mishra, A.K.; Mishra, A. Antifungal and antioxidative potential of oil and extracts derived from leaves of Indian spice plant Cinnamomum tamala. Cell. Mol. Biol. 2012, 58, 142-147.

42. Kumar, S.; Pandey, A.K. Chemistry and biological activities of flavonoids: An overview. Sci. World J. 2013, 2013, 162750. [CrossRef]

43. Şöhretoğlua, D.; Sarib, S.; Barutc, B.; Özelc, A. Tyrosinase inhibition by some flavonoids: Inhibitory activity, mechanism by T in vitro and in silico studies. Bioorg. Chem. 2018, 81, 168-174. [CrossRef]

44. Quan, N.V.; Xuan, T.D.; Tran, H.D.; Thuy, N.T.D.; Trang, L.T.; Huong, C.T.; Yusuf, A.; Tuyen, P.T. Antioxidant, $\alpha$-amylase and $\alpha$-glucosidase inhibitory activities and potential constituents of Canarium tramdenum bark. Molecules 2019, 24, 605. [CrossRef]

45. Su, C.; Hsu, C.; Huang, L. Inhibitory potential of fatty acids on key enzymes related to type 2 diabetes. BioFactors 2013, 39, 415-421. [CrossRef]

46. Su, C.H.; Lai, M.N.; Ng, L.T. Inhibitory effects of medicinal mushrooms on $\alpha$-amylase and $\alpha$-glucosidase enzymes related to hyperglycemia. Food Funct. 2013, 4, 644-649. [CrossRef]

47. Anh, L.H.; Xuan, T.D.; Thuy, N.T.D.; Quan, N.V.; Trang, L.T. Antioxidant and $\alpha$-amylase inhibitory activities and phytocompounds of Clausena indica Fruits. Medicines 2020, 7, 10. [CrossRef]

48. Kumar, S.; Kumar, V.; Prakash, O. Enzymes inhibition and antidiabetic effect of isolated constituents from Dillenia indica. Biomed Res. Int. 2013, 2013, 382063. [CrossRef]

49. Chahar, M.K.; Sharma, N.; Dobhal, M.P.; Joshi, Y.C. Flavonoids: A versatile source of anticancer drugs. Pharmacogn. Rev. 2011, 5, 1-12. [CrossRef]

50. Kopustinskiene, D.M.; Jakstas, V.; Savickas, A.; Bernatoniene, J. Flavonoids as anticancer agents. Nutrients 2020, 12, 457. [CrossRef] [PubMed]

51. Veeramuthu, D.; Raja, W.R.T.; Al-Dhabi, N.A.; Savarimuthu, I. Flavonoids: Anticancer properties. In Flavonoids—From Biosynthesis to Human Health; Justino, G.C., Ed.; IntechOpen: London, UK, 2017. [CrossRef]

52. Sakthivel, R.; Sheeja, D.; Kasi, M.; Devi, P. Phytol shows anti-angiogenic activity and induces apoptosis in A549 cells bydepolarizing the mitochondrial membrane potential. Biomed. Pharmacother. 2018, 105, 742-752. [CrossRef] [PubMed]

53. Alencar, M.V.O.B.; Islam, M.T.; Ali, E.S.; Santos, J.V.O.; Paz, M.F.C.J.; Sousa, J.M.C.; Dantas, S.M.M.M.; Mishra, S.K.; Cavalcante, A.A.C.M. Association of phytol with toxic and cytotoxic activities in an antitumoral perspective: A meta-analysis and systemic review. Anticancer Agents Med. Chem. 2018, 18, 1828-1837. [CrossRef]

54. Pejin, B.; Kojic, V.; Bogdanovic, G. An insight into the cytotoxic activity of phytol at in vitro conditions. Nat. Prod. Res. 2014, 28, 2053-2056. [CrossRef]

55. Sheeja, L.; Lakshmi, D.; Bharadwaj, S.; Parveen, K.S. Anticancer activity of phytol purified from Gracilaria edulis against human breast cancer cell line (MCF-7). Int. J. Curr. Sci. 2016, 19, 36-46.

56. de Alencar, M.V.O.B.; Islam, M.T.; de Lima, R.M.T.; Paz, M.F.C.J.; Dos Reis, A.C.; da Mata, A.M.O.F.; Filho, J.W.G.O.; Cerqueira, G.S.; Ferreira, P.M.P.; Sousa, E.J.M.C.; et al. Phytol as an anticarcinogenic and antitumoral agent: An in vivo study in swiss mice with DMBA-Induced breast cancer. IUBMB Life 2019, 71, 200-212. [CrossRef]

57. Song, Y.W.; Cho, S.K. Phytol induces apoptosis and ROS-mediated protective autophagy in human gastric adenocarcinoma AGS cells. Anal. Biochem. 2015, 4, 4. [CrossRef]

58. Endrini, S.; Rahmat, A.; Ismail, P.; Taufiq-Yap, Y.H. Cytotoxic effect of $\gamma$-sitosterol from Kejibeling (Strobilanthes crispus) and its mechanism of action towards c-myc gene expression and apoptotic pathway. Med. J. Indones. 2014, 23, 203. [CrossRef]

59. Sundarraj, S.; Thangam, R.; Sreevani, V.; Kaveri, K.; Gunasekaran, P.; Achiraman, S.; Kannan, S. $\gamma$-Sitosterol from Acacia nilotica L. induces G2/M cell cycle arrest and apoptosis through c-Myc suppression in MCF-7 and A549 cells. J. Ethnopharmacol. 2012, 141, 803-809. [CrossRef]

60. Teschke, R.; Xuan, T.D. Active nature-based ingredients for drug discovery with pivotal role of clinical efficacy: Review and prospective. J. Mod. Med. Chem. 2020, 8, 4-18. [CrossRef]

61. Teschke, R.; Larrey, D.; Melchart, D.; Danan, G. Traditional Chinese medicine (TCM) and herbal hepatotoxicity: RUCAM and the role of novel diagnostic biomarkers such as microRNAs. Medicines 2016, 3, 18. [CrossRef] [PubMed] 
62. Teschke, T.; Eickhoff, A.; Wolff, A.; Xuan, T.D. Liver injury from herbs and "dietary supplements": Highlights of a literature review from 2015 to 2017. Curr. Pharmacol. Rep. 2018, 4, 120-131. [CrossRef]

63. Teschke, T.; Xuan, T.D. Herbs including shell ginger, antioxidant profiles, aging, and longevity in Okinawa, Japan: A critical analysis of current concepts. In Aging, 2nd ed.; Preedy, V.R., Patel, V.B., Eds.; Academic Press: Cambridge, MA, USA, 2020; pp. 209-222. [CrossRef]

64. Teschke, R.; Xuan, T.D. Viewpoint: A contributory role of shell ginger (Alpinia zerumbet (Pers.) B.L. Burtt \& R.M. Sm) for human longevity in Okinawa, Japan? Nutrients 2018, 10, 166. [CrossRef]

65. Tropicos-Missouri Botanical Garden. Available online: https://www.tropicos.org/name/25509277 (accessed on 20 October 2020).

66. National Institute for Environmental Studies. Available online: https://www.nies.go.jp/biodiversity/invasive/DB/detail/8145 0e.html (accessed on 20 October 2020).

67. Invasive Weed; Japan Livestock Technology Association (JLTA): Tokyo, Japan, 1994; p. 31.

68. Elzaawely, A.A.; Xuan, T.D.; Koyama, H.; Tawata, S. Antioxidant activity and contents of essential oil and phenolic compounds in flowers and seeds of Alpinia zerumbet (Pers.) B.L. Burtt. \& R.M. Sm. Food Chem. 2007, 104, 1648-1653. [CrossRef]

69. Tuyen, P.T.; Xuan, T.D.; Khang, D.T.; Ahmad, A.; Quan, N.V.; Anh, T.T.T.; Anh, L.H.; Minh, T.N. Phenolic compositions and antioxidant properties in bark, flower, inner skin, kernel and leaf extracts of Castanea crenata Sieb. et Zucc. Antioxidants $2017,6,31$. [CrossRef]

70. Pellegrini, N.; Serafini, M.; Colombi, B.; Del Rio, D.; Salvatore, S.; Bianchi, M.; Brighenti, F. Total antioxidant capacity of plant foods, beverages and oils consumed in Italy assessed by three different in vitro assays. J. Nutr. 2003, 133, 2812-2819. [CrossRef]

71. Elzaawely, A.A.; Tawata, S. Antioxidant activity of phenolic rich fraction obtained from Convolvulus arvensis L. leaves grown in Egypt. Asian J. Crop. Sci. 2012, 4, 32-40. [CrossRef]

72. Quan, N.V.; Xuan, T.D.; Anh, L.H.; Tran, H.-D. Bio-guided isolation of prospective bioactive constituents from roots of Clausena indica (Dalzell) Oliv. Molecules 2019, 24, 4442. [CrossRef] 